\title{
The Effects of Dollarization on Human Resources in the Hospitality Industry in Zimbabwe
}

\author{
${ }^{1}$ Forbes Kabote, ${ }^{1}$ Sebastian Vengesayi, ${ }^{2}$ Patrick Walter Mamimine, \\ ${ }^{2}$ Rumbidzai Mataruse. \\ ${ }^{1}$ School of Hospitality and Tourism, Chinhoyi University of Technology, Zimbabwe, Private Bag 7724, \\ Chinhoyi, Zimbabwe \\ ${ }^{2}$ Department of Hospitality and Tourism, Chinhoyi University of Technology, Zimbabwe, Private Bag 7724, \\ Chinhoyi, Zimbabwe
}

\begin{abstract}
The study investigated effects of dollarization on Hospitality Industry's Human Resources. A qualitative study was done in hotels located at one of Zimbabwe's renowned tourist resort (Nyanga). Semi structured questionnaires were used to collect data and thematic data analysis adopted. Major issues to emerge from the study were improved employee performance, decreased staff turnover, high staff morale and improved employee benefits. It was concluded that apart from the disadvantage of the country's loss of monetary and fiscal sovereignty, dollarization positively affected the hospitality industry's human resources. It is therefore recommended that dollarization should continue in the Zimbabwean economy for continued benefits of employees and their families until such a time when introduction of local currency does not in any way erode the gains realised as a result of dollarization.
\end{abstract}

Keywords: Dollarization, Human Resources, Hospitality Industry, Zimbabwe,

\section{Introduction}

The performance of the hospitality industry in Zimbabwe declined from the year 2000 to 2008 [1]. This situation was attributed to economic decline, political instability, capital flight and damaged infrastructure [2]. The hyperinflation coupled with negative publicity in traditional source markets pushed hospitality organisations to lose faith in the local currency [Zimbabwe Dollar] [3]. As a result the hospitality industry's contribution to the Gross Domestic Product dropped by 5\% from 2000 to 2008 [3] and has since increased to $11 \%$ by end of 2011 , that is three years after dollarization.

The economic meltdown had ripple effects throughout the Zimbabwean economy with decline in the capacity of key productive sectors of the economy such as tourism, manufacturing and agriculture [4]. There were no new structures (hotels, lodgings) constructed during the economic crises era [3]. [5] noted that during the hyperinflation period there was human resources flight from the local industry into the Diaspora and the hospitality industry was not spared from this flight. In 2009 a multicurrency regime was introduced as part of the short term recovery programme (STERP) under the new coalition government [6]. The accepted currencies were United States Dollar (US\$), South African Rand (SAR), British Pound and Botswana Pula [7]. The government officially dollarized its economy upon presenting its national budget using the US dollar.

By dollarizing its economy, Zimbabwe had to grapple with two economic schools of thought. One school of thought advocated for dollarization for the purposes of eliminating hyperinflation overnight, eminent reduction in exchange rate volatility, reduction in the possibility of currency crises of devaluation and reduction in capital flight [8]. On the other hand were those against dollarization who argued that it would cause the richer to become richer and the poor to become poorer [9]. The two divergent schools of thought are well articulated in several post dollarization research in Zimbabwe [6;2; 10; 7]. It can therefore be posited that nobody had a clear picture at inception of how dollarization would affect the various sectors of the Zimbabwean economy. Thus the study objective was to investigate the effects of dollarization specifically on Zimbabwe's Human Resource base in the hospitality industry. Based on a case of selected hospitality establishments, the results would provide insights to hospitality practitioners on the dynamics of human resources management in a dollarized economy.

\section{Literature Review}

Dollarization has been defined as the adoption of the United States Dollar or any other major currency as the currency of choice by authorities of a country outside the United State as the legal tender or official currency [11; 7]. Dollarization can also be referred to as currency substitution, asset substitution, Randification or Eurorization $[12 ; 13]$. [14; 15] argue that dollarization is equivalent to having a fixed exchange rate regime. When dollarization takes place in a country or region, it does so through one of the three acknowledged forms as guided by the amount of legislation applicable in the country or region. Thus this defines dollarization as a 
process without a clear starting point but signals that prompt people to behave in a certain manner until an economy is fully dollarized [15]. There are three stages in the process to full dollarization according to [14]. These three are unofficial dollarization, semi-official dollarization and official dollarization.

According to [16 and 14] unofficial dollarization is also known as de facto dollarization. This is the spontaneous adoption of the dollar by the general public without support from government legislation. According to [8] unofficial dollarization in Zimbabwe started around 2000 and was ongoing until 2008. [8] argues that unofficial dollarization may also take the guise of currency substitution, assert substitution and liability substitution. This implies circulation of foreign currency among the general public without the approval from the officials such that if one is found in possession of foreign currency one will be arrested. During this period foreign currency will be dominating in the black market [17]. Zimbabweans were seen buying assets and investing in oil to preserve the value of their money.

[16 and 14] defines semi official dollarization as a situation where a country will be having two currency regimes, which are domestic (national) currency and foreign currency both being used at the same time in a country. The foreign currency will be used as a secondary legal tender thus being partially allowed to be used alongside domestic currency. At this stage of dollarization countries maintain their domestic central bank and conduct their own monetary policy [18]. At this stage prices in shops are either tagged in foreign currency or domestic currency [16]. In Zimbabwe licences were issued by the Reserve Bank of Zimbabwe to some organisations to do business in foreign currency during 2008 among them hospitality organisations [7]. Thus some hospitality organisations started trading in foreign currency before the official dollarization in Zimbabwe. According to [19] official dollarization can also be referred to as de jure. Official dollarization has been defined as the government legitimisation of the use of US Dollar. Legitimisation may be in any form ranging from simply declaring the dollar to be legal to total withdrawal of the domestic currency and abolishing all other legal tender $[16 ; 14 ; 15]$. According to [8] full dollarization is when foreign currency becomes the exclusive legal tender fulfilling the basic functions of money. The Zimbabwean economy was fully dollarized in February 2009 when the government officially accepted the use of US Dollar, South African Rand and any other major currency as the currency of choice [20]. At this period the Zimbabwe Dollar was eliminated from the economy leaving the US dollar being used as the main medium of exchange.

\subsection{Relevance of Dollarization}

[21] argues that dollarization takes various forms which are monetary, financial or real dollarization. Monetary dollarization is defined as the use of foreign currency and deposits in parallel with national currency for example United States Dollar and the Euro. Financial dollarization is the use of foreign currency in financial transaction and real dollarization is the use of foreign currency for wages goods and services. The process of dollarization starts with de facto to de jure is adopted by different people, sectors of the economy and government at different times for varying reasons [15]. In Zimbabwe all the three types of dollarization were experienced with differing effects on the economy and social life of the people [9]. At the time of writing Zimbabwe is a fully dollarized economy which has undergone the various processes, types and forms of dollarization.

According to [22] dollarization has merits to individuals, cooperates and nations at large. Of note is the elimination of hyperinflation $[4 ; 8]$. With a stable economy there is sustainable buying power for ordinary people, economic growth as exemplified by positive performances in all manufacturing industries in Zimbabwe after dollarization [10]. Like any other economic policy dollarization has its own demerits according to [10]. These includes eliminating local currency, hence Governments can no longer make their own monetary decisions in terms of monetary policy and fiscal policy. Countries also lose competitive advantage to its trading partners as it can no longer make its goods cheaper in the world-wide market by devaluing its currency thus it has lost the monetary sovereignty. Dollarization also does nothing to address the core problems that were dragging a country's economy such as the nation's woeful lack of infrastructure, lack of investment, expensive credit, low level of technology and high cost of production which impedes recovery of the productive sector as was experienced in Ecuador.

\subsection{The hospitality industry}

[23] defined hospitality as the act of receiving guests in a generous and cordial manner. The cumulative effect of the acts makes the industry comprise businesses that offer guests a home away from home. Thus according to [24] hospitality can be defined by its scope, mission and providers. [25] went on to state that hospitality concept pins on what tourists experiences as travellers such as food consumption, drink and accommodation in an environment away from home. There are a number of activities that defines hospitality such as accommodation, food and beverages, meetings and events, gaming, entertainment and recreation, travel and tourism and visitor information services [23]. However the delivery of consistent goods and service in the hospitality industry is affected by the nature of the industry. 
The hospitality industry is a service industry that is labour intensive which makes its delivery very complicated compared to manufacturing industries [26]. According to [27] service is an act of performance offered by one party (provider) to another (customer) that creates value and benefits for customers at specific times and places. The human resources play a significant part in delivering of services as they are acts [28]. Three main characteristics of hospitality products that are highly linked to human resources have been identified and these are intangibility, inseparability and heterogeneity (variability) [29].

Services by their nature can not be seen, tasted, felt or heard before they are bought. They are intangible and are unlike tangible products [30]. When guests depart from the hospitality establishment all they take with themselves are memories of their experiences at the hotel. These memories covers tangibles like food and drinks eaten, the bed slept in to intangibles like the ambience of the restaurant where the food was eaten and the way the staff of the hotel served them. According to [31] the need to tangibilise the hospitality product calls for the human resources to be highly involved in creating the memories that are worth taking with guests when they leave the hotel.

Inseparability refers to the simultaneous production and consumption of hotel products [27]. Thus both the service producer and consumer should be present for the transaction to occur [29]. The contact between the customer and employee shapes therefore the quality of service the customer eventually have and the memories they will take with themselves when they leave the organization to go back home. The inseparability nature of hospitality products thus highlights the important role played by the human resources in the successful enjoyment of hospitality products by customers.

Heterogeneity is sometimes referred to as variability. These are the inconsistencies in service quality that customers receive from hotels depending on the time, the context and the people present at the time of service delivery [27]. The people comprising the employees delivering the service and other customers define the quality, thus individual provider's skills and performance at the time of exchange are critical for an experience worth remembering [29]. For organizations to be known for certain standards their human resources must be able to provide similar and consistent service at all times. Thus human resource becomes critical in organizational success.

According to [30] one way that firms can differentiate themselves from competitors is by providing consistent high quality service. This they can achieve by exceeding the customer quality expectations [32]. Staff mobility and poor retention strategies may lead to loss of well trained staff and experienced staff which can have significant impact on service delivery [26]. [30] argues that professional human resources ensure memorable experiences for the customers. People employed in the tourism sector should do it with the necessary passion and as they love the type of work they are involved in [29].

\subsection{Dollarization and Hospitality Human resources}

Human resources are considered some of the most critical assets of any hospitality and tourism establishment [33;34]. This is due to the industry's service oriented nature as the employees are also part of the product itself. The personnel aspect of the industry however, is imbued with challenges. According to [33], hoteliers in Africa are more likely to cite labour shortages as a key concern. This is just one of the numerous challenges facing the hospitality sector. The findings of this study reinforce those of an earlier survey, which also found human resources to be a top concern of hotel managers.

Dollarization has proved to have considerable effects on economic sectors of nations [14]. According to [35] during inflationary periods employment becomes very unstable thus dollarization which brings an end to inflation is perceived as a solution to unemployment. Positive effects of dollarization on various economic sectors have been numerous [18; 8], Lucas 2009, Makina 2009 and [3]. To human resources in the hospitality sector dollarization has had mixed effects. On the positive dollarization has led to a drop in hospitality unemployment and employee motivation [35; 7]. However on the contrary [36] argues that as a result of dollarization of the economy, most salaries became inadequate for basic economic survival thus, though seemingly packaged as a sugar coated solution, dollarization is not always, the perfect solution.

According to [37] past research has failed to adequately consider the importance of interconnected human capital resources. [37] further contend that findings from such studies advance resource-based scholarship and highlight the value of understanding the relationships among human capital resources. Thus human resources cannot be isolated from capital resources, hence the need to investigate the effects of dollarization on Zimbabwe's hospitality industry human resources.

\section{Research Methodology}

The study was based upon fifty five semi structured interviews with hospitality industry employees. Five were human resources managers and fifty were general employees, all from five hospitality establishments in the Resort area of Nyanga, Zimbabwe. The respondents were purposefully selected from management and general staff with emphasis on representation of all departments and levels within the hotel [38]. A target of 
sixty was made but only fifty five could be interviewed with an average of eleven respondents per establishment.

Data was collected in September 2012. The data was later analysed thematically [39; 40]. The interviews followed a preset order of introduction, gathering of general information about the institution and the individuals. Interviews then placed emphasis on the main issues of the study which were, dollarization in general, hospitality human resources, dollarization and its impacts on hospitality human resources, factors that affects hospitality human resources performance and employees opinions on continued dollarization. With each interview lasting about thirty minutes, enough time was allowed for each participant to give their views on dollarization and the hospitality human resources. At the end of each day data collected was transcribed and filtered to remove irrelevant materials. Data analysis was done after all the fifty five respondents were interviewed. Using manual coding emerging themes were identified, presented and discussed. The major weakness of the study was that it was based on hotels located in a resort area, thus a comparative study in city hotels would compliment the results of this study. For confidentiality purposes the names of the establishments were omitted.

\subsection{Study area}

Nyanga is a huge and immense area consisting of a town, a few villages, the Rhodes Nyanga National Park, the highest mountain in Zimbabwe (Mount Nyangani) which is 2592 meters above sea level, as well as one of the highest waterfall in Africa (Mutarazi Falls) dropping 380 metres. There are also vast archaeological remains such as pathways, structures, ruins and iron artefacts that are found scattered amongst the open plains. Nyanga is rich of tourists' facilities and activities that include hiking, trout fishing, game viewing, golfing, nature walks, historical and educational tourism among others. Nyanga is located in the Nyanga District of Manicaland Province in Zimbabwe. It has an estimated population of 119370 people, and is one of many tourist resorts in Zimbabwe.

\section{Results And Discussion}

From the analysis of the data obtained through the interviews, six major themes were identified that explains the effects of dollarization on hospitality human resources. The six themes were (i) improved employee performance, (ii) decreased staff turnover, (iii) high morale among staff members, (iv) improved employee benefits, (v) improved employee health and (vi) better retirement packages. These are presented in detail below.

\subsection{Improved employee performance}

As a result of dollarization respondents were of the view that their performance at work had improved. The respondents highlighted that since dollarization guest complaints had diminished. The decline was attributed to the ripple effects of dollarization through improved staff commitment to work as they could see real value in the income they were earning compared to the pre-dollarization era. These results were in line with results from earlier work on dollarization and hospitality industry performance by same authors [7].

Respondents also highlighted that since dollarization there had been a marked decrease in wastage in the hotel. Wastage generated during the execution of work such as food preparation, service, laundry and general housekeeping exercises decreased. The respondents felt a sense of belonging to the organisation and thus as part of the organisation had a reason to protect or save the organisation's resources. This was unlike the pre-dollarization era where there was mistrust between employees and their employer (organisation) leading to neglect of duty which meant more cost to the organisation through unnecessary wastage. This observation strikes resonance with [35] who observed that employees begin to value their work as demand for jobs increase due to the associated value of the dollar being earned. Thus employee performance improved in post dollarization era.

Another dimension to emerge on improved employee performance was the sudden increase in tips from customers. Respondents argued that their performance in service delivery in the hotel had improved as indicated by the amounts of tips they were now receiving both as individuals and those put in the tip box. These results are in line with what [41] found that the better the service quality the higher the amount of tips given by customers. Considering the inseparability of the hospitality product one can conclude that human resources activities are equally responsible for the improved service quality and their activities that have become more customer focused has improved their performance and hence that of the organisation.

The last indicator identified by respondents as positive sign of their improved performance was the increase in average bed nights spent by guests at the hotel. Respondents indicated that a number of customers who had initially made a day or two day bookings were seen extending their stay by at least another day. Just as the old adage goes that unsatisfied customers vote with their feet by walking away, it is arguable that by extending their stay at the hotel customers were happy with what they were receiving. These findings support earlier work by [42] which attributed products, atmospherics and services to customer emotions and eventually 
to behavioural patterns. Other work by [43] also showed that service providers' performance had a big bearing on relationship quality and relationship continuity. Customer behaviours are a result of many factors and employee-customer relationship is fundamental hence the attribution of extended hotel stay to improved human resources performance.

\subsection{Staff turnover}

Dollarization has been attributed to reduction in staff turnover. Staff turnover is the movement of people into and out of employment within an organisation, it can be voluntary or involuntary [44]. According to [45] voluntary turnover is when the employee leaves on their own accord. On the contrary, involuntary is when the employees leave the organisations due to reasons independent of the affected employees such as downsizing or restructuring [46]. One of the most critical human resources challenges facing the hospitality industry's human resources is the high rate of staff turnover $[47 ; 48 ; 49 ; 50]$. Five common reasons have been identified for high turnover in the hospitality industry and these are; seasonal nature of the industry, organizational culture and leadership style, labour pool and labour shortages, customer service issues and pay rates and working hours $[51 ; 52 ; 53 ; 54 ; 55]$.

Upon dollarization there was a $30 \%$ decrease in staff turnover and eight new members were recruited. The results of the study were therefore in line with advocates for dollarization that claim that it reduces staff turnover and increases employment opportunities for people [35; 20]. The decline in staff turnover and increase in employment was welcome by employees as it reduced pressure and stress allowing employees to focus on their specific roles [56]. Thus organisational activities tend to flow smoothly; there is continued information sharing, reduction in recruitment costs to replace those that would have left and lastly a reduction in training costs for the organisation. Respondents were now able to work their normal shifts enabling them enough time to rest and prepare for their work. As a result their contribution to their work improved. According to [55] labour turnover can be a result of low pay rates and long working hours. During the pre-dollarization era salaries were being eroded by inflation rendering them worthless. The resultant staff turnover forced the few remaining staff members to work long hours to cover up for those that resigned [9]. The effect was more resignations and more pressure on the remaining members, a spiral effect and unhealthy situation that only dollarization managed to resolve rendering a positive human resource change in the hospitality industry.

\subsection{High staff morale}

The results of the study showed that since dollarization there had been improved staff morale in the hospitality industry. A number of issues were cited as indicators of high staff morale by staff members. One respondent gave the example of few conflicts among staff members after dollarization. During the predollarization period, employees were subject to a lot of work and stress thus they generally became depressed. Depressed employees, according to [57] are likely to have interpersonal conflicts and job dissatisfaction. This situation is not ideal for quality working relationships as employees depend on each for them to deliver excellent services to customers. With inseparability being critical in managing hospitality products, reduction in conflicts attributed to dollarization is more than welcome by hospitality human resources at their workplaces. According to one respondent the reduction in conflicts lead to improved teamwork among staff members rendering the work environment ideal for work.

Another dimension identified by respondents as leading to high morale was the support and high cooperation staff was now receiving from management. According to [58] positive management has big motivational effect on employees. Since dollarization management has been able to recruit, provide basic necessities for their staff and refurbish the establishment [7]. Thus management pressure also declined hence a change in how they dealt with their own staff. Without dollarization management would still be grumpy and difficulty to approach making it difficulty for staff to approach them and too long or forever to have support that they sometimes desperately needed both at work and in their personal lives.

The respondents also highlighted that since dollarization their morale had increased because of the urgent resolution of guest complains when they arose. During the hyperinflationary era before dollarization, it was difficulty to get the basic resources required for day to day running of the business [7]. Thus when guests complained for example about the quality of food or beverages being flat, it was difficulty to replace the ones served as management was too strict in stock management. Front line employees such as waiters and receptionists felt the pressure as they were the link between customers and back office staff including management. According to [59] outbursts are a result and they are directed towards people who sometimes do not have control or power to solve the problem like chefs. The change economic environment attributed to dollarization [6] has made it easy for management to swiftly resolve guest complains and address special guest requests. As a result staff has been able to leave a normal work life and hence high staff morale.

\subsection{Employee benefits}


According to [60] employee benefits are part of the payroll. More and more organizations are investing a significant portion of their resources towards employee benefits [61]. As such respondents look at these critically as they are part of their total package. The respondents indicated that since dollarization their benefits package has improved greatly. Areas sighted were the provision of new uniforms to replace old ones. The uniforms also aid in confidence building as staff deliver their duties.

Respondents also talked of the increase in quality and quantity of staff meals. This result support earlier work by [62] who argued that staff meals has an effect into the loyalty of staff to an organization and the quality of service that they give to the customers. Thus upon dollarization organization has been able to provide better staff meals which made respondents happier than before.

Other benefits that respondents identified includes improvement in the quality of hotel accommodation provided to staff, medical benefits, affordability and availability of medication, long term employment contracts as business grow after dollarization and lastly better retirement packages that would enable someone to start a new life after work. These employee benefits were critical to human resources in a hotel as alluded to earlier on by [63] and [64]. Dollarization thus remained at the centre of the betterment of employee benefits in hospitality industry in the eyes of the respondents.

\section{Conclusion}

The study was carried out to investigate the effects of dollarization on Zimbabwe's Hospitality Industry Human Resources. The results of the study showed that dollarization had a variety of effects on hospitality human resources. These were grouped into four key themes which are improved employee performance, decreased staff turnover, high morale among staff members and improved employee benefits at work. In conclusion the researchers noted that dollarization lead to stability in human resources in hospitality sector, development of healthier and happier human resource and staff commitment to work and organization. Thus the researchers made two recommendations. Firstly hospitality organizations should take full advantage of dollarization to ensure a better human resource that is willing to go an extra mile for the organization. Secondly dollarization should continue in Zimbabwe until such a time when the macroeconomic environment is ready for the introduction of Zimbabwe dollar for the good of the human resources, their families, organizations and the nation at large.

\section{References}

[1]. ZTA, Tourism Trends and Statistics Report, Zimbabwe Tourism Authority-2010

[2]. R.T. Karambakuwa, T. Shonhiwa, L. Murombo, F.N. Mauchi, N.R. Gopo, W. Denhere, F. Tafirei, A. Chingarande, and V. Mudavahu, The impact of Zimbabwe tourism authority initiatives on tourist arrivals in Zimbabwe (2008-2009). Journal of Sustainable Development in Africa, 13(6), 2011, 68-77.

[3]. N. Zunga, Zimbabwe Hospitality sector -Undeniable long term value given the country prime tourism assets, (IMARA investing, 2009).

[4]. G. Kararach, P. Kadenge, G. Guvheya, Currency Reforms in Zimbabwe: An analysis of possible currency regime, The African capacity Building Foundation, Occasional Paper No 1, 2011

[5]. G. Kanyenze, Beyond the enclave: Towards a pro-poor and inclusive development strategy for Zimbabwe. (Weaver Pr-2011).

[6]. R. Mangizvo, and S. Jerie, "Is Dollarization the Panacea for Zimbabwe's Economic Challenges", The Dyke: A Journal of Midlands State University, 5(1). 2011. 104-111.

[7]. F. Kabote, S. Vengesayi, C. Mapingure, K. Mirimi, F. Chimutingiza, and R. Mataruse, Employee perceptions of Dollarization and the Hospitality Industry Performance. Australian Journal of Business and Management Research, 2(10), 2013. 31-37.

[8]. P. Chitambara, Unpacking Dollarisation (part one-2009).

[9]. T. Chagonda, Teachers' and bank workers' responses to Zimbabwe's crisis: uneven effects, different strategies. Journal of Contemporary African Studies, 30(1), 2012. 83-97.

[10]. M. Mutengezanwa, F. Mauchi, K. Njanike, J. Matanga, and R.N. Gopo, The possibility of reintroducing the Zimbabwean dollar, Australian Journal of Business and Management Research, 2(06), 2012. 01-08.

[11]. H. Leavell, S. Hart, and C. Alan, The Dollarization of Argentina and Ecuador. Journal of International Business Research, 2(1). 2003.

[12]. G. Ortiz, Dollarization Mexico: causes and consequences, Journal of Money, Credit and Banking, 15(2), $1983.174-185$.

[13]. P. Alvarez-Plata, and A. Garcia-Herrero, To dollarize or to de-dollarize: Consequences for monetary policy. Papier préparé pour la Banque Asiatique de Développement, septembre-2007.

[14]. A. Hila, and J.W. Dean, Distributional effects of dollarisation: the Latin American case. Third World Quarterly, 25(3), 2004, 461482 .

[15]. K. Schuler, Some Theory and History of Dollarization, Cato Journal, 25(1), 2005, 115-125.

[16]. S. H. Hanke, Zimbabwe: From hyperinflation to growth. The CATO Institute, Development Policy Analysis No. 6, 2012.

[17]. D. Kha and A. Makochekanwa, Hyperinflation chaos and its impact on economic calculation in Zimbabwe: the case for the "black gold" standard. 2009

[18]. G. Ronnholm, The Dollarization process in Ecuadorian and El-Salvador- the motives, the political and economic outcomes and effects, Department of Political Science, Stockholm University-2007

[19]. A.M. Kutan, E. Ozsoz and E. W. Rengifo. Cross-sectional determinants of Bank Performance under deposit dollarization in emerging markets, Emerging Markets Review, 13(4), 2012. 478-492.

[20]. C. J. Richardson, Zimbabwe: Why Is One of the World's Least-Free Economies Growing So Fast?. The CATO Institute, Policy Analysis No. 722. 2013

[21]. Z. Bogetic, Official Dollarization: Current Experiences and Issues, Cato Journal, 20(2), 2000, 179-213. 
[22]. G. Kararach, P. Kadenge and G. Guvheya, Currency reforms in Zimbabwe: an analysis of possible currency regimes. opendocs.ids.ac.uk-2010.

[23]. P. Jones and A. Siag, A Re-Examination of the Factors That Influence Productivity in Hotels: A Study of the Housekeeping Function, Tourism and Hospitality Research, 9(3), 2009, 224-234.

[24]. H. Andrews, L. Roberts and T. Selwyn, Hospitality and eroticism, International Journal of Culture, Tourism and Hospitality Research, 1(3), 2007, $247-262$.

[25]. S. Page and J. Connell, Tourism: Volume 1, Sage Publications-2009,

[26]. C. H. Lovelock, J. Wirtz, H. T. Keh and X Lu, Services marketing in Asia: managing people, technology, and strategy. Prentice Hall-2002.

[27]. S. Kuslivan, Managing Employee Attitudes and Behaviours in the Tourism and Hospitality Industry, NOVA Science Publishers 2003,

[28]. P. Petcharak, The assessment of motivation in the Saint Paul Hotel employees (Doctoral dissertation, University of Wisconsin2002).

[29]. K. D. Hoffman, L. W. Turley and S. W. Kelley, Pricing retail services. Journal of Business Research, 55(12), 2002, 1015-1023.

[30]. P. Kotler, Marketing Management, The Millennium Edition, Prentice Hall of India Private Limited-2002.

[31]. G. Dominici and R.Guzzo, Customer Satisfaction in the Hotel Industry: A Case Study from Sicily, International Journal of Marketing Studies, 2(2), 2010, 3-12.

[32]. P. Kotler, J. Bowen and J. Makens, Marketing for Hospitality and Tourism (3rdEd). Prentice Hall-2004.

[33]. C. A. Enz, Human Resource Management A Troubling Issue for the Global Hotel Industry. Cornell Hospitality Quarterly, 50(4), 2009, 578-583.

[34]. [34] S. Kusluvan, Z. Kusluvan, I. Ilhan and L. Buyruk, The Human Dimension A Review of Human Resources Management Issues in the Tourism and Hospitality Industry. Cornell Hospitality Quarterly, 51(2), 2010, 171-214.

[35]. J. Rinne and C. S. Paramo, Labour Markets and Civil Service in Ecuador in F. V. Cibils, M. Giugale and E. Somensatto (Eds.), The International Bank for Reconstruction and Development/ The World Bank, Washington-2008.

[36]. E. Phillips, Dollarization, Distortion, and the Transformation of Work. A Changing, 345. 2008

[37]. R. E. Ployhart, C. H. Van Iddekinge and W. I. MacKenzie, Acquiring and developing human capital in service contexts: The interconnectedness of human capital resources. Academy of management journal, 54(2), 2011, 353-368

[38]. G. Valentine, Tell me about . . . using interviews as a research methodology, in: R. Flowerdew and D. Martin (Eds.), Methods in Human Geography: A Guide for Students Doing a Research Project,(Harlow: Pearson-2005, 110-127).

[39]. P. Brouder. Creative Outposts: Tourism's Place in Rural Innovation, Tourism Planning \& Development, 9(4), 2012 , $383-396$.

[40]. P. M. Quinn, Qualitative Research and Evaluation Methods (London: Sage-2002).

[41]. M. Lynn, Restaurant tipping and service quality A tenuous relationship. Cornell Hotel and Restaurant Administration Quarterly, 42(1), 2001, 14-20.

[42]. S. S. Jang and Y. Namkung, Perceived quality, emotions, and behavioral intentions: Application of an extended Mehrabian-Russell model to restaurants, Journal of Business Research, 62 (4), 2009, 451-460.

[43]. W. G. Kim and Y. Cha, Antecedents and consequences of relationship quality in hotel industry. International Journal of Hospitality Management, 21(4), 2002, 321-338.

[44]. A. Denvir and F. McMahon, Labour turnover in London hotels and the cost effectiveness of preventative measures Int. Journal of Hospitality Management, 11(2), 1992, 143-54.

[45]. J. D. Wilson, Examining job embeddedness survey items for an adventure education population. scholarworks.iu.edu-2010.

[46]. V. Y. Haines 111, P. Jalette and K. Larose, The influence of human resource management practices on employee voluntary turnover rates in the Canadian non governmental sector. Industrial and Labor Relations Review, 2010, 228-246.

[47]. C. Lashley and B. Rowson, Lifestyle businesses: Insights into Blackpool's hotel sector. International Journal of Hospitality Management, 29(3), 2010, 511-519.

[48]. T. R. Hinkin and J.B. Tracey, The cost of turnover. Cornell hotel and restaurant administration quarterly, 41(3), 2000. 14-21.

[49]. K. Chalkiti and M. Sigala, Staff turnover in the Greek tourism industry: a comparison between insular and peninsular regions. International Journal of Contemporary Hospitality Management, 22(3), 2010, 335-359.

[50]. S. Kuria, A. Ondigi and P. M. Wanderi, Assessment of Causes of Labour Turnover in Three and Five Star-Rated Hotels in Kenya, International Journal of Business and Social Science, 3(15), 2012, 311-317.

[51]. M. J. Boella, Human Resource Management in the Hospitality Industry, Stanley Thornes-1996.

[52]. H. Nadiri and C. Tanova, An investigation of the role of justice in turnover intentions, job satisfaction, and organisational citizenship behaviour in hospitality industry. International Journal of Hospitality Management, 29(1), $2010,33-41$.

[53]. J. M. Poulston, Working conditions in hospitality: Employees' views of the dissatisfactory hygiene factors. Journal of Quality Assurance in Hospitality and Tourism, 10(1), 2009, 23-43.

[54]. S. M. Radzi, S. Z. A. Ramley, M. Salehuddin, Z. Othman and M. H. Jalis, An empirical assessment of hotel departmental managers turnover intentions: The impact of organisational justice. International Journal of Business and Management, 4(8), 2009, $173-183$.

[55]. A. Brien, The New Zealand hotel industry: Vacancies increase while applicant numbers and calibre decrease. International Journal of Hospitality and Tourism Administration, 5(1), 2004, 87-103.

[56]. D. Baker-McClearn, K. Greasley, J. Dale and F. Griffith, Absence management and presenteeism: the pressures on employees to attend work and the impact of attendance on performance. Human Resource Management Journal, 20(3), 2010, 311-328.

[57]. P. C. Pilette, Presenteeism in nursing: a clear and present danger to productivity. Journal of Nursing Administration, 35(6), 2005, 300-303

[58]. J. Walters and J. Walters, Positive Management: Increasing Employee Productivity. Business Expert Press-2010.

[59]. D. Dann and T. Hornsey, Towards a theory of interdepartmental conflict in hotels. International Journal of Hospitality Management, 5(1), 1986, 23-28.

[60]. M. O. Angela, The hidden payroll: Employee benefits and the structure of workplace inequality. In Sociological Forum, 1(4), 1986, 657-683.

[61]. B. T. Beam Jr and J. J. McFadden, Employee benefits. Real Estate Education Company-2001.

[62]. R. B. Brown and D. Keegan, Humor in the hotel kitchen. Humor, (12), 1999, 47-70.

[63]. K. Meudell and K. Rodham, Money isn't everything... or is it? A preliminary research study into money as a motivator in the licensed house sector. International Journal of Contemporary Hospitality Management, 10(4), 1998, 128-132. 